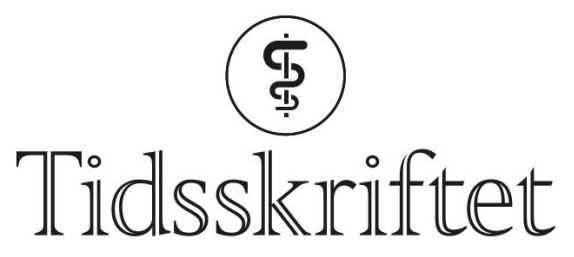

DEN NORSKE LEGEFORENING

\title{
Den neste pesten?
}

ESSAY

\section{KRISTINE HUSØY ONARHEIM}

E-post: kristine.onarheim@uib.no

Kristine Husøy Onarheim er LIS1-lege i Sandøy kommune. Hun har ph.d. i globale helseprioriteringer.

Hoste. Halsvondt. Feber. Det blir vanskeligere å tenke, det blir vanskeligere å puste. Svartedauden. Spanskesyken. H1N1. Ebola. En smittsom, svært dødelig bakterie eller virus er infeksjonsmedisiners frykt, en WHO-direktørs mareritt, en politikers store test og vår alles ukjente fiende. I spenningsromanen Som pesten velter et lite virus et stort lass. Vil den neste pesten få helsevesenet til å kollapse?

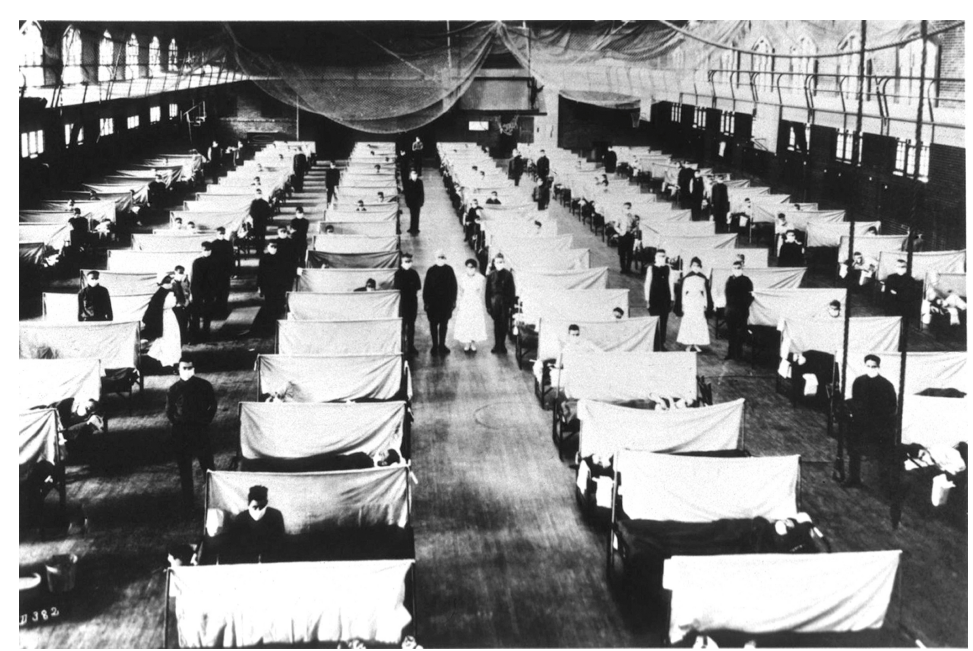

En amerikansk skolegymsal gjort om til sykehus for spanskesykepasienter i 1918-19. Sykdommen gjorde en tredjedel av verdens befolkning syke og drepte mellom 50 og 100 millioner. Foto: Everett Collection / NTB scanpix

I Hanne-Vibeke Holsts Som pesten bryter en uvanlig dødelig og virulent influensavariant ut. Det finnes ikke vaksine eller gode medisiner. Verken helsevesenet, politikere eller byråkrater i Verdens helseorganisasjon (WHO) er forberedt på en ny influensapandemi - en stor en. Som i møter med Yersinia pestis i tidligere tider ødelegger og paralyserer utbrudd av smittsomme sykdommer oss alle.

Bakteriologer, medisinere, historikere og andre har studert Justinian-pesten (541-44), Svartedauden (1347-50) og andre utbrudd av byllepest (1). I nyere tid har sars, ebola og svineinfluensa utfordret svake og syke, til tross for at sykehusene og behandlingsmulighetene er bedre enn noen gang. Under spanskesyken for hundre år siden ble $1 / 3$ av verdens befolkning (50o millioner mennesker) syke, og 50-10o millioner mennesker døde (2). 
I bautasteinen Holst har skrevet, møter vi den første kasuspasienten i Ukraina. Like etter slår den første influensabølgen innover Danmark: «... etter få ukers influensaepidemi er det lovpriste danske helsevesenet, på tross av fine beredskapsplaner og vakre hensiktserklæringer, tvunget i kne.» På sykehusene finnes det verken nok plass eller personale. Operasjoner må flyttes, kreftsyke får ikke cellegift og andre pasienter sendes hjem fordi influensarammede trenger rommene. Samtidig har den danske infeksjonsmedisineren Karoline Branner nettopp startet som koordinator for å lede WHOs pandemiberedskap i Genève. På jakt etter smittebærere, oppdatert informasjon og en mulig vaksine, møter Branner storpolitikken, BigPharma - og i en pageturner skal også kjærligheten blomstre og fallere.

\section{Medisin, litteratur og realisme?}

Den mest kjente beskrivelsen av den store pesten er kanskje fra den franske forfatteren og filosofen Albert Camus (1913-6o) (3). I det fiktive landet Oran, som rammes av en byllepest, blir byens innbyggere nektet utreise og venter sakte, men sikkert på sin skjebne.

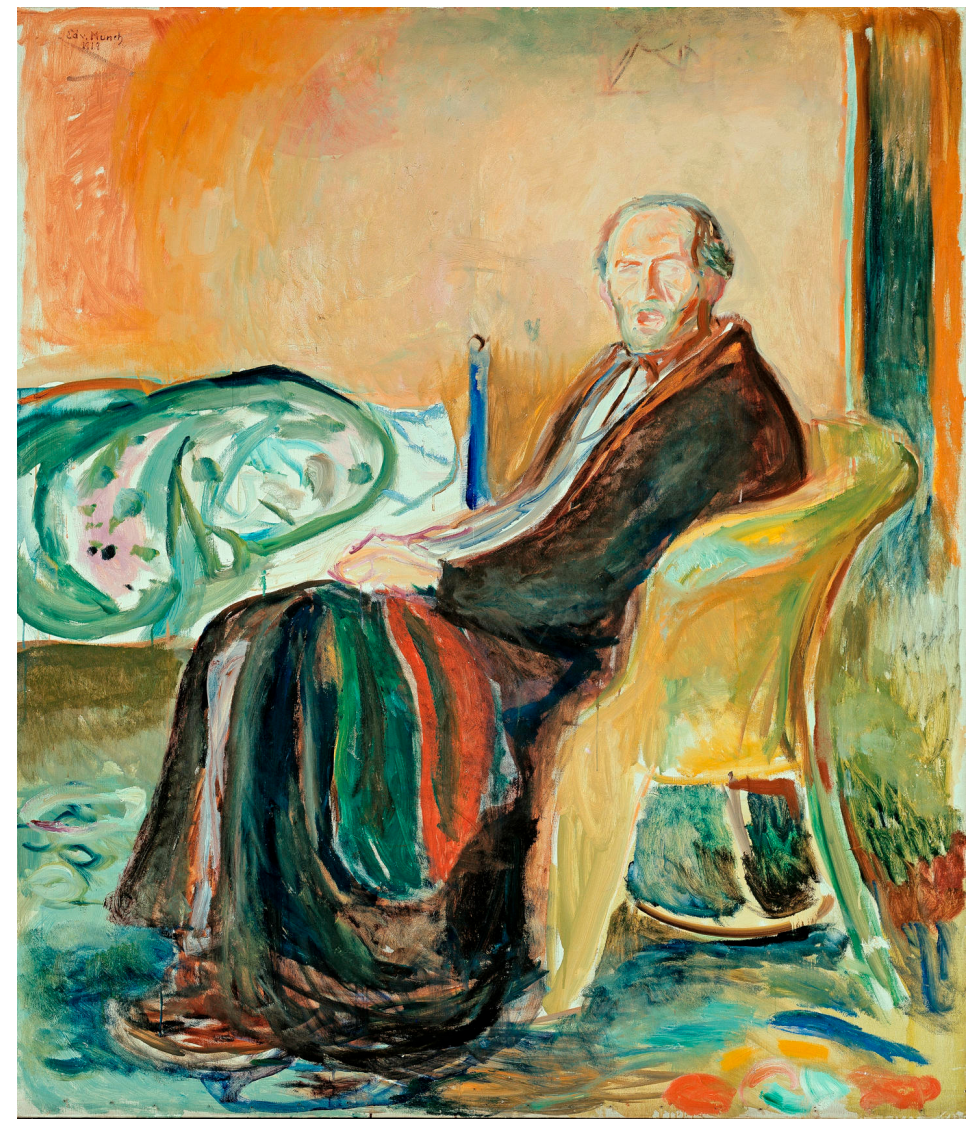

Edvard Munchs Selvportrett med spanskesyken, 1919. Foto: Alamy stock photo

Når medisinen skildres i skjønnlitteratur eller andre fortellinger, er verden ofte mer svart/hvitt, men også mer glamorøs enn hverdagen jeg opplever som lege i spesialisering. Hva så med Holsts beskrivelser av influensapandemien? Virologene og mikrobiologene kan diskutere realismen i spenningsromanens oppdiktede influensavirus bedre enn jeg. Men sommeren 2016 tilbrakte jeg i WHOs trange korridorer i Genève, et hovedsete for internasjonal helsepolitikk og diplomati. Det er også i disse gangene deler av handlingen i Som pesten utspiller seg. I julivarmen i WHO-bygget virket ventilasjonsanlegget heller dårlig, og datamaskinene ga om mulig enda større frustrasjoner enn klagene vi hører på sykehusavdelinger og legekontorer landet over. Men møtene i hovedkvarteret er viktige. WHO er den normative lederinstitusjonen for global helse og har ansvar for oppfølgingen av de internasjonale helsereguleringene. I hovedkvarteret blir det tatt valg om hvilke tema som skal prioriteres. Skal fokus være på antibiotikaresistens eller mental helse? På hvilke måter kan WHO uttale seg om seksuell helse og abort? Når er et influensautbrudd en pandemi? Gjennom et sammensurium av møter, rapporter, Skype-samtaler, lunsjer, 
drinker og sammenkomster, er det her mye av agendaen settes. Som pesten skildrer nesten skremmende godt hvordan global helsediplomati er en blanding av fag, storpolitikk og kompromisser. Og som i skjønnlitteraturen er kanskje det som sies i gangene og under middagene vel så viktig som det som sies på møtene - både i Genève og andre steder.

\section{Hvem skal få?}

Et av spørsmålene Holst løfter frem, er hvem som skal få vaksine når ikke alle kan få. Hvordan skal den nye vaksinen fordeles: til de som trenger den mest, til de unge eller til de gamle, til de fattige eller til de rike? Fra møter med enkeltpasienter i allmennpraksis til helsepolitiske diskusjoner i WHO står ulike interesser i konflikt. Prioriteringsspørsmålene er medisinske, men har også økonomiske, sosiale og etiske konsekvenser. Hvis pesten eller influensaen kom til Norge, hvordan ville vi ha håndtert det? Teoretisk prioritering versus reell prioritering kan være to ulike verdener. For som det illustreres i boken, oppleves det å «beskytte seg selv» stadig mer aktuelt når det høyvirulente viruset kommer nærmere. Men hva skjer da med dårligere stilte grupper? Prioritering kan bety å fremme like muligheter til å overleve eller å sikre lik tilgang til vaksine. Å prioritere de med best muligheter til å overleve kan gå på bekostning av de med dårligere helse i utgangspunktet. Når ikke alle kan få tilgang til en ny vaksine eller helsetjeneste, vil det påvirke enkeltmenneskers mulighet til å overleve. Ved en pandemi vil fordeling av vaksinene også virke inn på videre smittespredning i befolkningen.

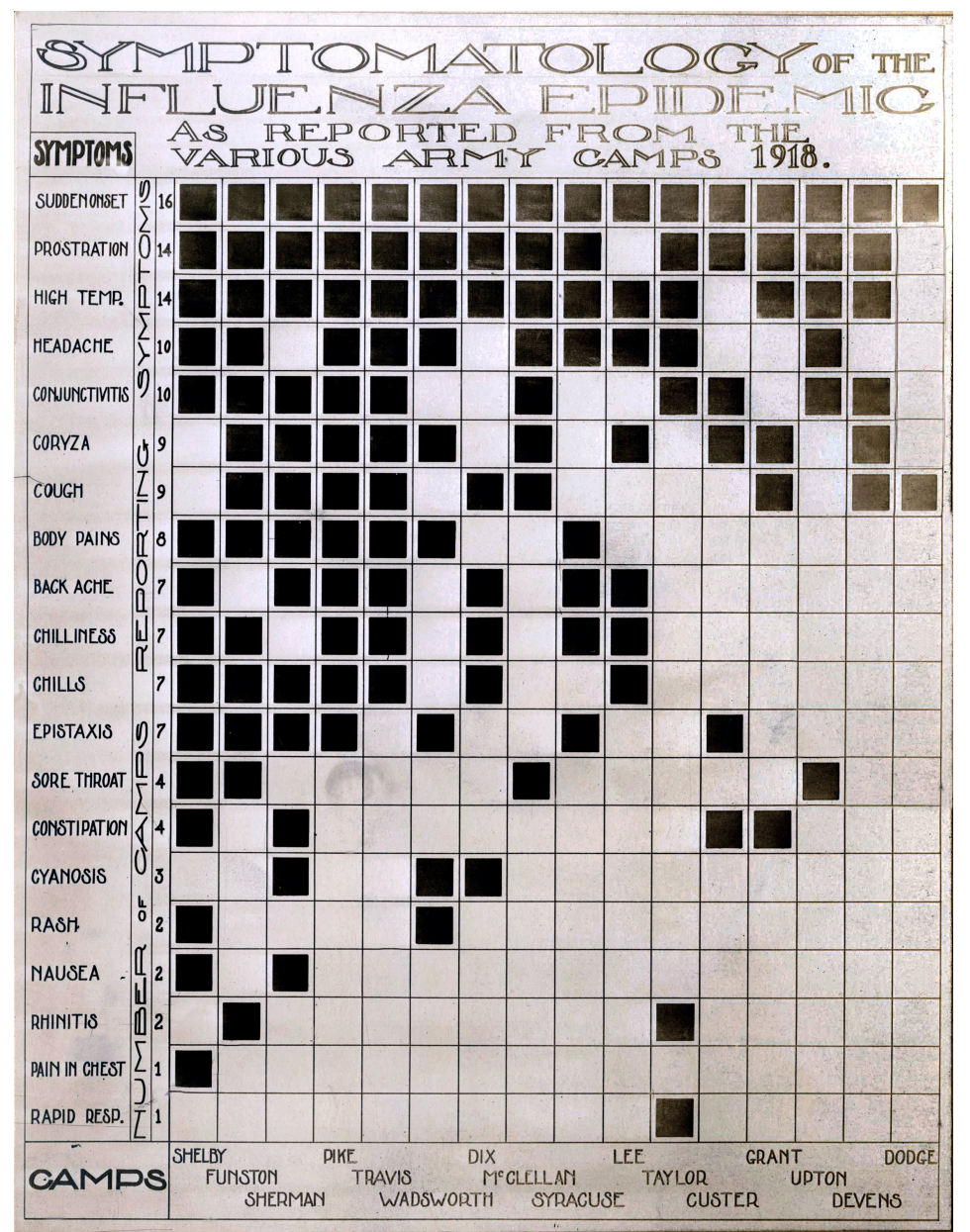

Figur som viser symptomene på spanskesyken som ble rapportert av amerikanske militcerleirer $i 1918$. Influensa og lungebetennelse drepte flere amerikanske soldater og sjømenn under krigen enn fiendens våpen. Foto: Science Photo Library / NTB Scanpix

I Norge er det relativt bred enighet om at prioriteringer bør skje basert på vekting av ulike kriterier, sikret gjennom åpne prosesser (4). Tre kriterier er sentrale for å sikre rettferdige helseprioriteringer: nytte, ressurs og alvorlighet (4). Vil norske helsemyndigheter og politikere forsvare disse prinsippene også hvis vi blir rammet av en ny pest? Jeg håper det, 
men er usikker. Hvordan vil vi reagere når det er våre egne barn som ikke får vaksine? Hva om det er nabokommunen som har dårlig tilgang? Blir vi mindre påvirket av sykdom og elendighet som utspiller seg langt unna, blant ukjente mennesker? Og bør det være slik, dersom disse ukjente trenger vaksinen mer enn deg og meg?

Helse eller folks beste er ikke nødvendigvis fokus når beslutningene tas

Om bokens influensavirus - som gir høyere risiko for død hos en etnisk gruppe - er realistisk, kan diskuteres, men eksempelet illustrerer et sentralt etisk dilemma: Skal de dårligst stilte bli prioritert? De med størst sannsynlighet for å bli syke, kan få mest nytte av vaksinen, men i boken er det absolutt ikke de som kommer først i køen. Holst viser hvordan ingen planlagt strategi for fordeling av vaksiner kan gi prioritet til de sosioøkonomisk sterkeste i samfunnet.

Det norske helsevesenet har som mål å sikre likebehandling og rettferdig fordeling av helse og helsetjenester (4). Til tross for økende anerkjennelse av begrensede ressurser, er diskusjonene i media og Beslutningsforum oftere på hva vi skal prioritere opp, som dyre nye medisiner og teknologi, heller enn hva vi skal prioritere ned. Dette kan føre til at de som ikke roper høyest - de "tause taperne» - ikke blir prioritert. For å sikre de svakestes interesser er det viktig å fortsette å utfordre disse svakhetene.

\section{Helse $=$ internasjonal storpolitikk}

Frykten for en pandemi har gitt økt oppmerksomhet på global helsesikkerhet, med fokus på beredskap og håndtering av mulige framtidige helsekriser (5). Fordi verden består av uavhengige stater, anser vi ofte fordelingsspørsmål som noe landene selv bør håndtere. Men i møte med et virus som ikke respekterer landegrenser, viser Holst hvordan fordeling av vaksiner, når hele verdens befolkning potensielt trenger dem, er et internasjonalt anliggende. Prioriteringsspørsmålene blir enda vanskeligere. For å være forberedt på den neste pesten, trenger vi rettferdige styringsmekanismer i internasjonal helsepolitikk $(6,7)$. En pandemi krever forberedelse, beredskap, teknologisk utvikling og produksjon av nye vaksiner og medisiner, men gir også samfunnsmedisinske og etiske utfordringer: Er det et internasjonalt ansvar å gi råd om fordeling av vaksiner eller nye medisiner? Hvem skal ta avgjørelsen om hvem som skal få? Hva er risikoen ved ikke-fullt utprøvde vaksiner? Hvordan skal vaksinen nå befolkningen den sikter mot? Hvordan skal myndighetene kommunisere det de vet - og ikke vet - om fordeler, ulemper og risiko (8)? 


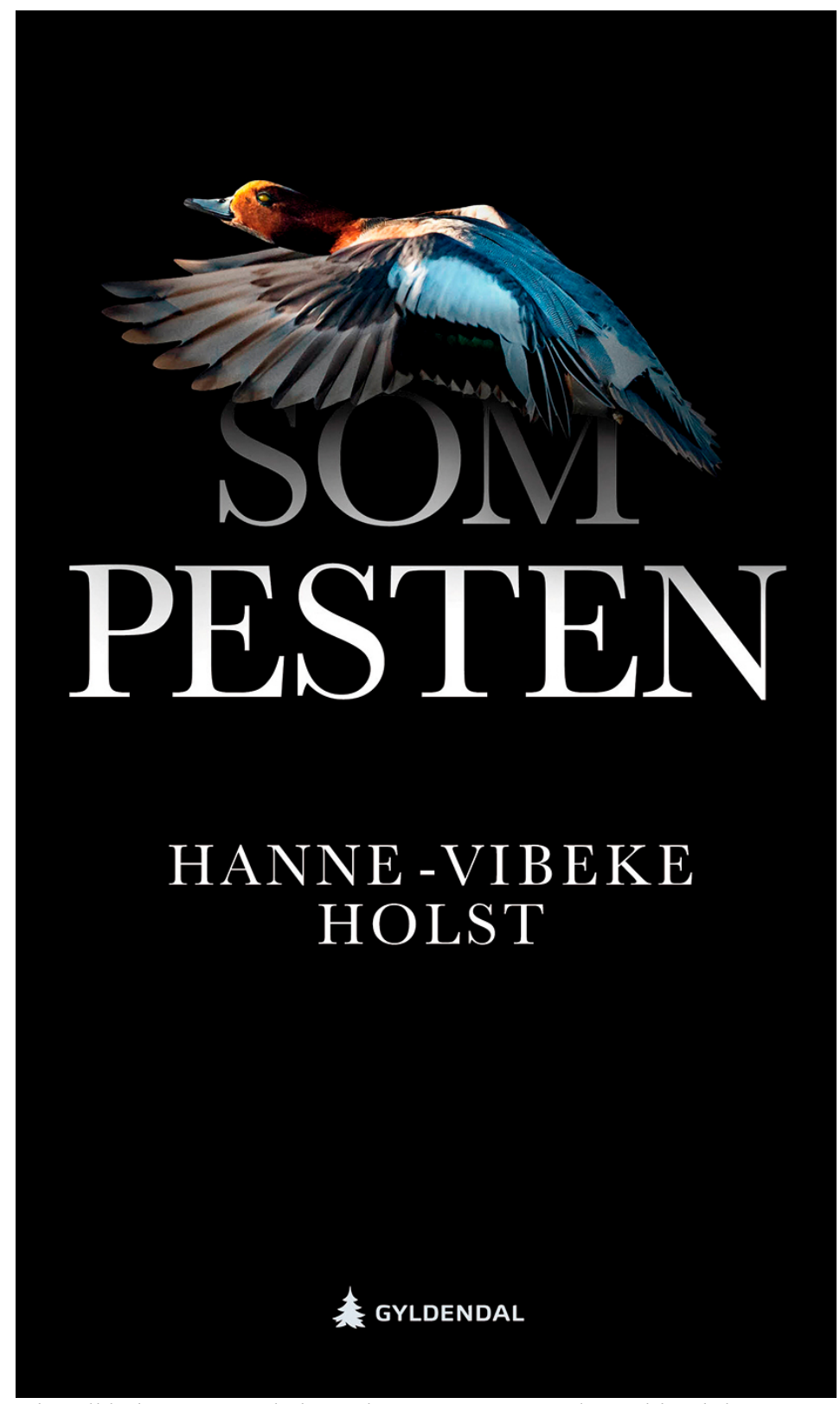

Aktuell bok: Hanne-Vibeke Holst. Som pesten. Oslo: Gyldendal, 2018

Uten å røpe for mye, kommer den etterlengtede vaksinen etter hvert på plass i Som pesten. Boken avdekker svakheter i produksjon og pris på nye og ettertraktede legemidler, som henger tett sammen med virkeligheten. Med et begrenset antall vaksiner stiger prisen ved $\emptyset$ kende etterspørsel. De rike og velstående har bedre kjøpekraft og makt enn fattigere land og grupper. H1N1-utbruddet i 2009 (svineinfluensa) viste hvordan europeiske land fikk tidligere tilgang til influensavaksiner enn andre $(9,10)$. USA - med $4,5 \%$ av verdens befolkning - hadde forhåndsbestilt over $30 \%$ av verdens vaksiner (11). I boken holder mektige internasjonale aktører, som BigPharma, russiske og amerikanske myndigheter, kortene tett til brystet for å verne om egne pasienter så vel som økonomiske interesser.

Global helsepolitikk framstilles ofte i norske medier som en «bistandsgreie» - som handler om de andre. Men som både det fabrikkerte viruset i boken, ebolautbruddet i 2014 og norske diskusjoner om H1N1 viser, er politikken til stede i helsepolitikken - både hjemme og ute. Global helse i 2019 er ikke tradisjonell bistandspolitikk, men internasjonale floker og samarbeid, der egenhensyn spiller viktigere rolle enn flere tør å innrømme. Når egeninteresser og realpolitikk tar stor plass, er sivilsamfunnet og organisasjoner som Leger Uten Grenser eller Røde Kors viktige, særlig for vern av de svakeste. I en skjønnlitterær roman er de gode og onde partene trolig mer karikerte enn i den virkelige verden, men det overdrevne bildet er nok mer riktig enn vi skulle ønske. Diskusjoner om Syria i FNs sikkerhetsråd, eller tilgang til medisiner i WHO eller WTO (World Trade Organization) er 
ikke bare tekniske dokumenter, men ofte kompromisser etter storpolitiske diskusjoner: Helse eller folks beste er ikke nødvendigvis fokus når beslutningene tas.

Det handler ikke om det blir en ny pest, men hvilken pest det blir og når den kommer

\section{Den neste pesten?}

Det ryktes om at boken skal bli tv-serie, og med sitt skremmende pandemibilde, sin dramatiske utvikling og svart/hvitt-tilnærming kan det bli god underholdning. Men for oss som lever i virkeligheten: Når kommer den neste pesten? Klarer vi å respondere på utfordringene i møte med et kjent eller ukjent virus eller bakterie? Historien viser hvordan utbrudd av pest, influensa og andre smittsomme sykdommer setter både helsevesen og lokalsamfunn på prøve. Ebolaepidemien i 2014/15 ble et tragisk eksempel på hvordan et lite virus utløser et stort kaos - med helsemessige, menneskelige, sosiale, økonomiske og politiske konsekvenser (6). Selv om utbruddet ble mindre enn fryktet, viste epidemien tydelig hvordan de hardest rammede landene og det internasjonale systemet ikke var godt nok rustet - verken til å forebygge eller respondere når utbruddet kom. Flere rapporter pekte på hvordan systemene for deling av informasjon, kunnskap og teknologi ikke fungerte og at sentrale aktører som WHO viste manglende lederskap (6). Likevel ga også utbruddet nye muligheter. Blant annet ble en ny vaksine utviklet i et internasjonalt samarbeid få hadde sett for seg tidligere $(12,13)$.

Selv om vi ikke kjenner den neste pesten, er de lærde sikre på at den kommer (14). Det handler ikke om det blir en ny pest, men hvilken pest det blir og når den kommer. WHO leder nå arbeidet for å gjøre oss bedre rustet både til å forstå hvilken pest eller hvilke virus som kommer og til å skaffe løsninger tidlig nok. Det gjelder å ikke ende opp i en ny «too little, too late» (15). Mens vi venter, kan vi heldigvis lese bøker.

\section{LITTERATUR:}

1. Spilde I. Var den store pesten egentlig pest? Forskning.no.

https://forskning.no/sykdommer-pest-historie/var-den-store-pesten-egentlig-pest/1032752 Lest 10.1.2019.

2. Taubenberger JK, Morens DM. 1918 Influenza: the mother of all pandemics. Emerg Infect Dis 2006; 12: 15-22. [PubMed][CrossRef]

3. Camus A. Pesten. Oslo: Den norske bokklubben, 2010.

4. Meld. St. 34 (2015-2016). Verdier i pasientens helsetjeneste-Melding om prioritering. https://www.regjeringen.no/no/dokumenter/meld.-st.-34-20152016/id2502758/ Lest 10.1.2019.

5. Puyvallée AB, Kittelsen SK, Storeng KT. Krise! Hvordan beredskapslogikk endrer global helsepolitikk. Tidsskr Nor Legeforen 2018; 138. doi: 10.4045/tidsskr.18.0572. [PubMed][CrossRef]

6. Moon S, Sridhar D, Pate MA et al. Will Ebola change the game? Ten essential reforms before the next pandemic. The report of the Harvard-LSHTM Independent Panel on the Global Response to Ebola. Lancet 2015; 386: 2204-21. [PubMed][CrossRef]

7. Frenk J, Moon S. Governance challenges in global health. N Engl J Med 2013;368: 936-42. [PubMed][CrossRef]

8. Lee BY, Moss WJ, Privor-Dumm L et al. Is the world ready for an Ebola vaccine? Lancet 2015;385: $203-4$. [PubMed][CrossRef]

9. Johansen K, Nicoll A, Ciancio BC et al. Pandemic influenza A(H1N1) 2009 vaccines in the European Union. Euro Surveill 2009; 14: 19361. [PubMed]

10. Friede M, Palkonyay L, Alfonso C et al. WHO initiative to increase global and equitable access to influenza vaccine in the event of a pandemic: supporting developing country production capacity through technology transfer. Vaccine 2011; 29 (suppl 1): A2-7. [PubMed][CrossRef]

11. Brown D. Vaccine would be spoken for; rich nations have preexisting contracts. The Washington 
Post 7.5.2009.

http://www.washingtonpost.com/wp-dyn/content/article/2009/05/o6/AR200905060376o.html.

Lest 24.2.2019.

12. Henao-Restrepo AM, Longini IM, Egger M et al. Efficacy and effectiveness of an rVSV-vectored vaccine expressing Ebola surface glycoprotein: interim results from the Guinea ring vaccination cluster-randomised trial. Lancet 2015;386: 857-66. [PubMed][CrossRef]

13. Henao-Restrepo AM, Camacho A, Longini IM et al. Efficacy and effectiveness of an rVSV-vectored vaccine in preventing Ebola virus disease: final results from the Guinea ring vaccination, open-label, cluster-randomised trial (Ebola Ça Suffit!). Lancet 2017;389: 505-18. [PubMed][CrossRef]

14. Nuki P, Shaikh A. Scientists put on alert for deadly new pathogen - 'Disease X'.

https://www.telegraph.co.uk/news/2018/03/o9/world-health-organization-issues-alert-disease-x/ Lest 12.1.2019.

15. Røttingen JA, Gouglas D, Feinberg M et al. New vaccines against epidemic infectious diseases. N Engl J Med 2017; 376: 610-3. [PubMed][CrossRef]

Publisert: 14. juni 2019. Tidsskr Nor Legeforen. DOI: 10.4045/tidsskr.19.0044

(C) Tidsskrift for Den norske legeforening 2020. Lastet ned fra tidsskriftet.no 